\title{
Micropropagation of Caralluma adscendens var. fimbriata-An Indigenous Medicinal Plant of India
}

\author{
Ramachandra Naik $\mathbf{M}^{1 *}$, Rajappa Joga $\mathrm{J}^{2}$, Nagaraja $\mathbf{N}^{1}$, Nagashree $\mathbf{B}^{1}$, Shankramma $\mathbf{N}^{1}$, Chanda $\mathrm{P}^{3}$, Gusain $\mathrm{P}^{4}$ and Krishnamurthy $\mathrm{YL}^{1}$ \\ ${ }^{1}$ Department of PG, Studies and Research in Applied Botany, Kuvempu University, Shimoga, Karnataka, India \\ ${ }^{2}$ Division of Natural Resource Management (Agroforestry), ICAR Research Complex for NEH Region, Umiam, Meghalaya, India \\ ${ }^{3}$ Department of Veterinary Microbiology, Indian Veterinary Research Institute-Regional Station, Kolkata, West Bengal, India \\ ${ }^{4}$ Department of Botany and Microbiology, HNB Garhwal University, Srinagar, Garhwal, Uttarakhand, India
}

"Corresponding author: Ramachandra Naik M, Department of PG, Studies and Research in Applied Botany, Kuvempu University, Shimoga-577451 Karnataka, India, Tel: 9196207 20591; E-mail: rcnaik1@gmail.com

Received date: July 02, 2017; Accepted date: August 25, 2017; Published date: September 17, 2017

Copyright: ( 2017 Ramachandra Naik M, et al. This is an open-access article distributed under the terms of the Creative Commons Attribution License, which permits unrestricted use, distribution, and reproduction in any medium, provided the original author and source are credited.

\begin{abstract}
Present study describes micro-propagation of traditionally important medicinal plant in northern interior part of Karnataka, Caralluma adscendens var. fimbriata, for its conservation. Results showed that the survival ability of regenerated plants was 84 per cent. Proliferation of $C$. adscendens var. fimbriata shoots was achieved on medium supplemented with various concentrations of different hormones. The effective combination of 6-Benzylaminopurine (BA) $2.0 \mathrm{mg} / \mathrm{l}$ along with $0.5 \mathrm{mg} / \mathrm{l}$ kinetin $(\mathrm{Kn})$ and $0.2 \mathrm{mg} / \mathrm{l}$ Indole-3-acetic acid (IBA) produced highest number of shoot sprouting frequency $(91 \%)$ with a mean of $2.60 \pm 0.17$ shoot number per explants and a mean shoot length of $3.88 \pm 0.20 \mathrm{~cm}$ from the mature nodal explants. A good frequency of callus was induced in 1.5 to $2.0 \mathrm{mg} / \mathrm{l}$ of 1 Naphthaleneacetic acid (NAA) and in $2.0 \mathrm{mg} / \mathrm{l}$ of 2,4-dichlorophenoxy acetic acid (2, 4-D) were transferred to root induction media. The NAA showed positive response of rooting when compared with IAA and IBA in the present study. The best root and shoot sprouted plants were successfully acclimatized in the greenhouse and transferred to open field conditions. This micropropagation protocol can be successfully used for large-scale multiplication and conservation of germplasm of this threatened plant.
\end{abstract}

Keywords: Micro propagation; Caralluma adscendens var. fimbriate; Hardening

\section{Introduction}

The genus Caralluma R. Br (Sensu lato) belongs to Apocynaceae sub family Asclepiadoideae is represented by 13 species and 5 varieties in India [1]. Caralluma diffusa (wight) N.E.Br. C. stalagmifera, $C$. stalagmifera var. longipetala, $C$. adscendens var. fimbriata, and Caralluma nilagiriana are considered as endemic in south India [2]. In the last comprehensive review of Caralluma (Sensu lato), [3] accepted 57 species arranged in several sub-genera.

All the species of Caralluma prefer dry conditions and decay when exposed to excess of water. It is commonly grows on sloppy areas and found amidst boulders (rock crevices) and some grows midst of thorny bushes [4]. The thorny shrubs support the growth, development and protection of Caralluma (Sl). Several species of Caralluma are consumed as famine food and has several medicinal properties like anti-inflammatory, anti-nociceptive, anti-ulcer, anti-diabetic, carminative, febrifugal, anti-pyretic and antioxidant property [5]. The extract of $C$. adscendens var. fimbriata, are used in the form of capsules “GENASLIM" for body weight loss [6].

These plants due to their several medicinal values are fast disappearing and are threatened to become rare due to indiscriminate collection and over exploitation by the pharmaceutical industry, agriculture, mining activities, and lopping for fodder [7]. Advantage of excellent tools of biotechnological methods for culturing plant cells and tissues offers a useful means for conservation and propagating valuable, rare and endangered medicinal species. Large numbers of medicinal plants have been successfully employed for in vitro culture technique are Fabiana imbricate [8], Thapsia garganica [9], three varieties of Caralluma adscendense [10], Caralluma stalagmifera [11] and Caralluma edulis [12]. BA is a synthetic cytokinin that deduce plant growth and development responses by stimulating cell division. The effect of BA on multiple shoot bud differentiation has been demonstrated in a number of cases using a variety of explants [13]. In this study, 6-Benzylaminopurine $(2.0 \mathrm{mg} / \mathrm{l})$ in combination with kinetin $(0.5 \mathrm{mg} / \mathrm{l})$ and Indole-3-acetic acid $(0.2 \mathrm{mg} / \mathrm{l})$ produced highest number of shoot sprouting frequency $(91 \%)$ from the mature nodal explants. Kn as a growth regulator enables the production of stock plants. Along with addition of 2,4-dichlorophenoxy acetic acid (2,4-D) in the medium, Kn exhibits significant percentage response, number of shoots per explant and shoot length [14]. In the present study, Kn (2.5 $\mathrm{mg} / \mathrm{l})$ in combination with BA $(2.0 \mathrm{mg} / \mathrm{l})$ inducted shoot multiplication and well developed sprouting frequency of shoots at an enhanced pace by subsequent cultures were observed which is in agreement with the earlier reports on other Asclepiadacean medicinal plants, such as Gymnema sylvetre [15] and Hemidescus indicus [16]. NAA is a most favored auxins for shoot culture has been used this study at different concentrations $(0.2$ to $1.0 \mathrm{mg} / \mathrm{l})$ along with 2,4 -D have produced swollen shaped callus, dedifferentiated and developed into friable callus culture and well-formed embryoid. With combination of BA (1.0 $\mathrm{mg} / \mathrm{l})$ and IAA $(0.2 \mathrm{mg} / \mathrm{l})$, NAA $(0.1 \mathrm{mg} / \mathrm{l})$ produced a maximum number of shoots with sprouting frequency of $2.87 \pm 0.21$ from callus. A good frequency of callus was induced in 1.5 to $2.0 \mathrm{mg} / \mathrm{l}$ of 1 Naphthaleneacetic acid (NAA) and in $2.0 \mathrm{mg} / \mathrm{l}$ of 2,4-dichlorophenoxy acetic acid (2, 4-D) were transferred to root induction media. The 
NAA showed positive response of rooting when compared with IAA and IBA in the present study. The NAA showed positive response of rooting when compared with IAA and IBA in the present study. The best root and shoot sprouted plants were successfully acclimatized in the greenhouse and transferred to open field conditions.

In present study we aimed to develop an efficient in vitro method for conservation and mass propagation of Caralluma adscendens var. fimbriata through nodal segment culture and callus to somatic embryogenesis, followed by successful restoration of the micropropagated plants into field conditions in North interior part of Karnataka, India.

\section{Plant material and surface sterilization}

Plants of $C$. adscendens var. fimbriata were collected from scrubby vegetated habitats of Alrameswara and Ramagiri villages of Chitradurga District (Figure 1a) are potted and maintained in polyhouse, Department of Applied Botany, Kuvempu University, Shivamogga, Karnataka.

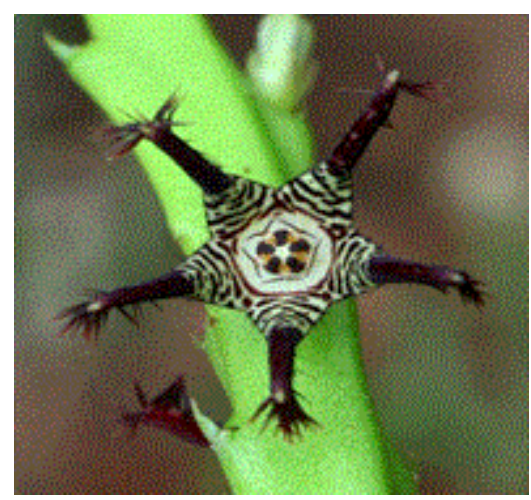

Figure 1a: Inflorescence of $C$. adscendens var. fimbriate.

Mature shoot segments with six to eight inter nodal plant segments were collected from the polyhouse and washed with running tap water for $15 \mathrm{~min}$ to remove the soil particles and other extraneous fine particles. The internodes were rinsed with $1 \%(\mathrm{v} / \mathrm{v})$ Tween-20 (Merck) for $5 \mathrm{~min}$ with constant agitation. Then they were rinsed in distil water thrice. The plant materials were immersed in 30 percent ethanol for 3 min and again washed with sterilized double distilled water followed by 0.1 per cent $(\mathrm{v} / \mathrm{v}) \mathrm{HgCl}_{2}$ treatment for $5 \mathrm{~min}$. Finally, the explants were thoroughly rinsed with sterile double distilled water for 2 to 3 times, and they were trimmed into pieces of about $0.6 \mathrm{~mm}$ to $1 \mathrm{~cm}$ and then inoculated on to MS (Murashige and Skoog, HiMedia) media, containing 3 per cent $(\mathrm{w} / \mathrm{v})$ sucrose and 0.8 per cent of agar. The $\mathrm{pH}$ of media was adjusted to 5.8 prior to autoclaving at $121^{\circ} \mathrm{C}$ for $20 \mathrm{~min}$.

Inoculations were carried out in a laminar airflow chamber to maintain aseptic sterile environment. The mature stem explants inoculated were incubated in the culture room. The cultures were maintained at 2000 lux light under cool white, fluorescent tubes. The photoperiod was adjusted as $16 \mathrm{~h}$ light and $8 \mathrm{~h}$ dark diurnal cycle by using an electric timer. The temperature was adjusted about $25 \pm 2^{\circ} \mathrm{C}$ by means of air conditioners.

Shoot induction: For shoot induction, the nodal explants were cultured on MS medium supplemented with various plant growth regulators like $(\mathrm{BA})$ and $(\mathrm{Kn})$ at different concentrations $(0.5,1.0,2.0$,
3.0 and to $5.0 \mathrm{mg} / \mathrm{l})$. The induced shoots were sub-cultured on to the fresh medium after every month. The frequency of shoots produced from explants, the number of shoots per explants and the shoot length were recorded after six weeks of culture.

Callus induction and multiplication: Internodal segments of $C$. adscendens var. fimbriata were cultured on MS medium fortified with different auxins, like 2, 4-D and NAA at different concentrations (0.1 to $1 \mathrm{mg} / \mathrm{l})$. The tissues were sub-cultured on fresh medium once after every month. The frequency of explant produced into swollen shaped callus and well formation of embryos were transferred to fresh MS medium supplemented with different concentrations of NAA, IAA and BAP $(0.1$ to $0.5 \mathrm{mg} / \mathrm{l})$. The initiation of mature shoots from the callus was recorded after 16 days.

Root initiation and multiplication: The shoots regenerated directly from explants with 4 to $5 \mathrm{~cm}$ in length and shoots induced by callus with 2 to $3 \mathrm{~cm}$ in height were separated and individual shoots were transferred for rooting to half-strength MS medium containing different concentrations of NAA, IAA and IBA. Observations were made for the number of roots, and their lengths were measured.

Acclimatization and transplantation of plantlets: The well rooted plants with 3-5 leaves were carefully removed from the culture tubes and washed under running tap water to remove traces of agar. Then, the plantlets were planted onto plastic pots containing a cocopeat, cocopeat with sand and cocopeat with soil. The plastic pots were covered with transparent polythene cover to maintain humidity until the development of new rudimentary leaves and sprouting of new roots. After one month, the surviving plants were transferred to plastic pots under the green house containing forest natural soil followed by pouring of tap water for every alternative day maintained under green house condition. After one month, the frequency of survival was calculated.

Statistical analysis: The experiments were set up in a ten replicates in completely randomized design and data was collected after 2 months of inoculation. Data was analyzed to detect significant differences among the means [17], Variability in data has been expressed otherwise as mean \pm standard error.

\section{Results and Discussion}

Results of micro propagation showed that cultural conditions were found to influence the pattern of growth during in-vitro regenaration of $C$. adscendens var. fimbriata stem explants.

\section{Influence of cytokinins}

All concentrations of BA and $\mathrm{Kn}$ showed the best morphogenetic response and shoot sprouting frequency. MS medium containing BA was more effective than Kn for inducing proliferation of auxiliary buds as in previous reports [18-20]. However, the multiplication of the shoot sprouting frequency and shoot length showed immense responses supplemented with different concentration of the growth regulator BA $(0.5,1.0,1.5,2.0,2.5)$ and $\mathrm{Kn}(1.0,1.5,2.0,2.5,3.0)$ respectively (Table 1).

In the present study, the combination of BA $(2.0 \mathrm{mg} / \mathrm{l})$ and $\mathrm{Kn}(2.5$ $\mathrm{mg} / \mathrm{l})$ resulted in the induction of shoot multiplication and welldeveloped sprouting frequency of shoots. The shoot multiplication at an enhanced pace by subsequent cultures were observed in the study is in agreement with the earlier reports on other Asclepiadacean medicinal plants, such as Gymnema sylvetre [15] and Hemidescus 
Citation: Ramachandra Naik M, Rajappa Joga J, Nagaraja N, Nagashree B, Shankramma N, et al. (2017) Micropropagation of Caralluma adscendens var. fimbriata-An Indigenous Medicinal Plant of India. Nat Prod Chem Res 5: 278. doi:10.4172/2329-6836.1000278

Page 3 of 8

indicus [16]. Low concentration of $\mathrm{Kn}(1.0-2.0 \mathrm{mg} / \mathrm{l})$ and BA (0.5 mg/l) yielded the suppression of shoot sprouting and number of shoots per explants. We have found that BA and Kn growth regulators showed the best morphogenic response and shoot sprouting frequency. MS medium containing BA was more effective than Kn for inducing proliferartion of axillary buds. Also, 2, $4 \mathrm{D}$ and NAA different concentrations auxins frequency with explant produced swollen shaped callus and well-formed embryoid. The survival ability of regenerated plants was 84 per cent [10], where $65 \%$ survival rate was found in $C$. adscendens var fimbriata.

\begin{tabular}{|c|c|c|c|c|}
\hline Hormone & Growth regulator (mg/l) & $\begin{array}{l}\text { Shoot sprouting frequency } \\
\text { (\%) }\end{array}$ & $\begin{array}{l}\text { Mean shoot number per explants } \\
\pm \text { SE }\end{array}$ & $\begin{array}{l}\text { Mean length of shoots }(\mathrm{cm}) \pm \\
\text { SE }\end{array}$ \\
\hline \multirow[t]{5}{*}{ BAP } & 0.5 & 35 & $1.45 \pm 0.11$ & $1.77 \pm 0.14$ \\
\hline & 1.0 & 52.5 & $1.50 \pm 0.11$ & $2.38 \pm 0.15$ \\
\hline & 1.5 & 62.5 & $1.75 \pm 0.12$ & $2.58 \pm 0.17$ \\
\hline & 2.0 & 75 & $2.30 \pm 0.13$ & $3.25 \pm 0.18$ \\
\hline & 2.5 & 65 & $2.05 \pm 0.14$ & $2.80 \pm 0.20$ \\
\hline \multirow[t]{5}{*}{$\mathrm{Kn}$} & 1.0 & 15 & $1.20 \pm 0.08$ & $1.48 \pm 0.10$ \\
\hline & 1.5 & 35 & $1.50 \pm 0.12$ & $2.18 \pm 0.12$ \\
\hline & 2.0 & 45 & $1.45 \pm 0.11$ & $2.44 \pm 0.09$ \\
\hline & 2.5 & 57.5 & $1.75 \pm 0.11$ & $2.64 \pm 0.21$ \\
\hline & 3.0 & 47.5 & $1.70 \pm 0.11$ & $2.54 \pm 0.16$ \\
\hline \multicolumn{3}{|l|}{ F value } & 6.89 & 9.45 \\
\hline
\end{tabular}

Table 1: Effect of various concentrations of BA and Kn on shoot formation in mature nodal explants of $C$. adscendens var. fimbriata cultured on MS medium with $3 \%$ sucrose.

\section{Influence of cytokinins with auxin on shoot multiplication}

Morphogenetic expression of nodal explants cultured on MS medium supplemented with different concentration of auxins and cytokinins is shown in Table 2. Various concentrations and combination of hormones like BA $(1.5,2.0 \mathrm{mg} / \mathrm{l}), \mathrm{Kn}(0.2$ to $2.0 \mathrm{mg} / \mathrm{l})$, NAA $(0.2$ to $1.0 \mathrm{mg} / \mathrm{l})$ and IAA $(0.2,0.4$ and $0.6 \mathrm{mg} / \mathrm{l})$ has been used for the standardization. The preliminary studies proved that the nodal explants on BA $(1.5 \mathrm{mg} / \mathrm{l})$ and $\mathrm{Kn}(0.4 \mathrm{mg} / \mathrm{l})$ produced highest number of shoot sprouting frequency of about 76 per cent, the mean shoot/ explants observed was $2.05 \pm 0.15$ and mean shoot length was $2.93 \pm$ $0.17 \mathrm{~cm}$. followed by the concentration of BA $(1.5 \mathrm{mg} / \mathrm{l})$ and $\mathrm{Kn}(0.6$ $\mathrm{mg} / \mathrm{l})$ produced responded to 73 per cent of shoot sprouting frequency, the mean of shoot number per explants was about $1.95 \pm 0.15$ and the mean shoot length was $2.74 \pm 0.17$ (Table 2).

\begin{tabular}{|l|l|l|l|l|l|l|l|}
\hline BA & Kn & NAA & IAA & $\begin{array}{l}\text { Shoot sprouting } \\
\text { frequency (\%) }\end{array}$ & $\begin{array}{l}\text { Mean shoot number per } \\
\text { explants } \pm \text { SE }\end{array}$ & $\begin{array}{l}\text { Mean length of shoots (cm) } \\
\pm \text { SE }\end{array}$ & $\begin{array}{l}\text { Basal } \\
\text { (CP) }\end{array}$ \\
\hline 1.5 & 0.2 & & & 66.6 & $1.85 \pm 0.15$ & $2.74 \pm 0.17$ & - \\
\hline 1.5 & 0.4 & & & 76.3 & $2.05 \pm 0.15$ & $2.93 \pm 0.17$ & - \\
\hline 1.5 & 0.6 & & & 73.0 & $1.95 \pm 0.15$ & $2.94 \pm 0.14$ & - \\
\hline 1.5 & 0.8 & & & 63.3 & $1.60 \pm 0.14$ & $2.66 \pm 0.13$ & - \\
\hline 1.5 & & 0.3 & & 60.0 & $1.45 \pm 0.11$ & $2.08 \pm 0.13$ & + \\
\hline 1.5 & & 0.5 & & 53.3 & $1.55 \pm 0.11$ & $2.24 \pm 0.12$ & + \\
\hline 1.5 & & 1.0 & & 40.0 & $1.45 \pm 0.12$ & $1.77 \pm 0.12$ & + \\
\hline & 1.0 & 0.5 & & 43.3 & $1.50 \pm 0.12$ & $1.45 \pm 0.11$ & ++ \\
\hline & 1.5 & 0.5 & & 53.3 & $1.55 \pm 0.11$ & $2.47 \pm 0.11$ & ++ \\
\hline & 2.0 & 1.0 & & 40.0 & $1.30 \pm 0.12$ & $1.54 \pm 0.09$ & ++ \\
++
\end{tabular}


Citation: Ramachandra Naik M, Rajappa Joga J, Nagaraja N, Nagashree B, Shankramma N, et al. (2017) Micropropagation of Caralluma adscendens var. fimbriata-An Indigenous Medicinal Plant of India. Nat Prod Chem Res 5: 278. doi:10.4172/2329-6836.1000278

Page 4 of 8

\begin{tabular}{|c|c|c|c|c|c|c|c|}
\hline 2.0 & 0.4 & & & 85.0 & $2.10 \pm 0.15$ & $3.22 \pm 0.18$ & - \\
\hline 2.0 & 0.6 & & & 76.6 & $2.05 \pm 0.16$ & $3.07 \pm 0.11$ & - \\
\hline 2.0 & & 0.2 & & 66.6 & $1.90 \pm 0.12$ & $2.78 \pm 0.13$ & - \\
\hline 2.0 & & 0.4 & & 73.3 & $1.90 \pm 0.12$ & $2.76 \pm 0.18$ & + \\
\hline 2.0 & & 0.5 & & 70.0 & $1.60 \pm 0.12$ & $2.62 \pm 0.16$ & + \\
\hline 2.0 & 0.5 & 0.5 & & 63.3 & $1.85 \pm 0.12$ & $2.85 \pm 0.15$ & + \\
\hline 2.0 & 1.0 & 0.5 & & 60.6 & $1.55 \pm 0.10$ & $2.70 \pm 0.14$ & ++ \\
\hline 2.0 & 0.5 & & 0.2 & 91.0 & $2.60 \pm 0.17$ & $3.88 \pm 0.20$ & - \\
\hline 2.0 & 0.5 & & 0.4 & 87.0 & $2.20 \pm 0.18$ & $3.27 \pm 0.12$ & - \\
\hline 2.0 & 0.5 & & 0.6 & 70.0 & $1.90 \pm 0.11$ & $2.88 \pm 0.13$ & - \\
\hline \multicolumn{5}{|c|}{$F$ value } & 5.50 & 16.4 & \\
\hline
\end{tabular}

Table 2: Effect of different combination of BAP, Kn, NAA, and IAA on shoot regeneration of mature nodal explant of $C$. adscendens var.fimbriata.

The concentration of BA $(2.0 \mathrm{mg} / \mathrm{l})$ and $\mathrm{Kn}(0.4 \mathrm{mg} / \mathrm{l})$ yielded maximum shoots regeneration frequency responded to 85 per cent. Number of shoot per explants was $2.10 \pm 0.15$ and $3.22 \pm 0.18 \mathrm{~cm}$ mean shoot length, followed by other concentrations of hormone BA $(2.0 \mathrm{mg} / \mathrm{l})$ and NAA $(0.4 \mathrm{mg} / \mathrm{l})$ induced a shoots sprouting frequency of about 73.3 per cent, and their mean shoots per explants was $1.90 \pm$ 0.12 and mean shoot length was $2.76 \pm 0.18 \mathrm{~cm}$, followed by the other shoot sprouting frequency by different hormone concentrations. Some explants showed decreased sprouting frequency of shoot number/ explants and mean shoot length due to the formation of basal callus (Table 2).

Similarly, the combination of BA $(2.0 \mathrm{mg} / \mathrm{l}), \mathrm{Kn}(0.5 \mathrm{mg} / \mathrm{l})$ and IAA $(0.2 \mathrm{mg} / \mathrm{l})$ showed higher shoot regeneration frequency of about 91 per cent, the number of shoot per explants was $2.60 \pm 0.17$ and mean shoot length was $3.88 \pm 0.20 \mathrm{~cm}$ (Figure $1 \mathrm{~b})$. In combination of BA $(2.0$ $\mathrm{mg} / \mathrm{l}), \mathrm{Kn}(0.5 \mathrm{mg} / \mathrm{l})$ and IAA $(0.4 \mathrm{mg} / \mathrm{l})$ showed the shoots sprouting frequency of about 87 per cent, the number of shoots per explants was $2.20 \pm 0.18$ and mean shoot length was $3.27 \pm 0.12 \mathrm{~cm}$ followed by other combinations of cytokinins with auxins showed medium results with basal callus formation and other detailed resulted data was given in Table 2. Similar observation was reported in Hedeoma multiflorum [21] and Melissa officinalis [22]. The synergistic effect of auxin and cytokinin has been demonstrated in several medicinal plants, viz. Santoina canescens, Rauvolfia tetraphylla [23], Bupleurum fruticosum [24] and Psoralea corylifolia (Figures 1c and 1d).

\section{Somatic embryogenesis}

Slices of tender succulent shoots cultured on various concentrations of $2.4 \mathrm{D}$ ( 0.5 to $2.0 \mathrm{mg} / \mathrm{l})$ and NAA ( 0.5 to $2.0 \mathrm{mg} / \mathrm{l})$ became swollen, dedifferentiated and developed into friable callus after two weeks of culture. Globular embryos were formed directly on the surface of the callus within 3 weeks of culture (Figure 1e). The combination of BA $(1.0 \mathrm{mg} / \mathrm{l})$, IAA $(0.2 \mathrm{mg} / \mathrm{l})$ and NAA $(0.1 \mathrm{mg} / \mathrm{l})$ produced a maximum number of shoots with sprouting frequency of $2.87 \pm 0.21$ from callus (Figure 1f).
Hormone 2, 4-D at $1.5 \mathrm{mg} / \mathrm{l}$ showed maximum frequency of callus formation. The callus thus formed were cut into small fragments and cultured on the same induction medium. 2, 4-D (2.0 mg/l) and BA (0.1 $\mathrm{mg} / \mathrm{l}$ ) are needed for callus induction in Asclepias tuberosa [25]. In case of an Asclepiad, Tylophora indica produced callus on 2, 4-D hormone [13] and Hemidesmus indicus on BA cytokinine [26].

\section{Rooting of regenerated shoots}

Lower concentration of NAA at $0.1 \mathrm{mg} / \mathrm{l}$ induced high frequency of 89 per cent rooting, $5.40 \pm 0.27$ number of roots per shoot and mean root length of $5.78 \pm 0.19 \mathrm{~cm}$. this is followed by NAA $(0.2 \mathrm{mg} / \mathrm{l})$ which has induced high frequency of rooting at 86 per cent and number of roots per shoots is $3.82 \pm 0.14$ and mean root length is $4.25 \pm 0.22 \mathrm{~cm}$. No rooting was observed at higher concentration of NAA from the shoots. NAA was found to be good for inducing roots of Caralluma adscendens var. fimbriata (Figure $1 \mathrm{~g}$ ).

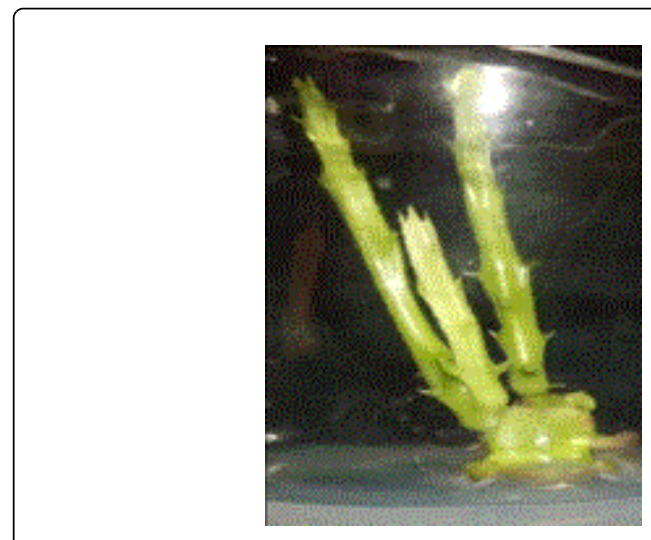

Figure 1b: Shoot induction from MS medium containing BA (2.0 $\mathrm{mg} / \mathrm{l})+\mathrm{Kn}(0.5 \mathrm{mg} / \mathrm{l})+\mathrm{IAA}(0.2 \mathrm{mg} / \mathrm{l})$. 
Citation: Ramachandra Naik M, Rajappa Joga J, Nagaraja N, Nagashree B, Shankramma N, et al. (2017) Micropropagation of Caralluma adscendens var. fimbriata-An Indigenous Medicinal Plant of India. Nat Prod Chem Res 5: 278. doi:10.4172/2329-6836.1000278

Page 5 of 8

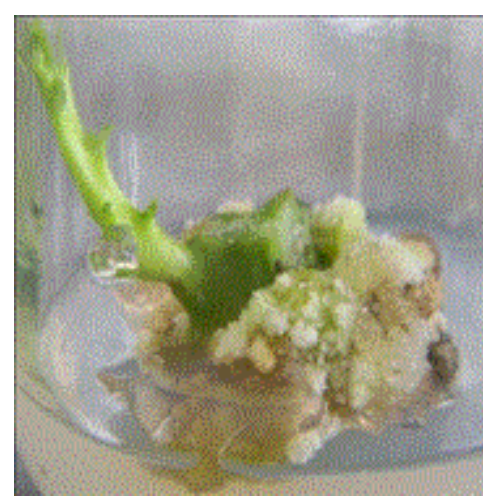

Figure 1c: Shoots and Callus induction from medium containing 1.5 $\mathrm{mg} / \mathrm{l} \mathrm{BA}+1 \mathrm{mg} / \mathrm{l} \mathrm{NAA}$.

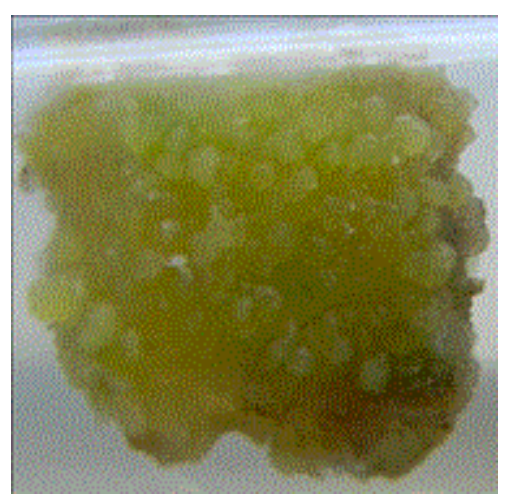

Figure 1d: Somatic embryoids Callus.

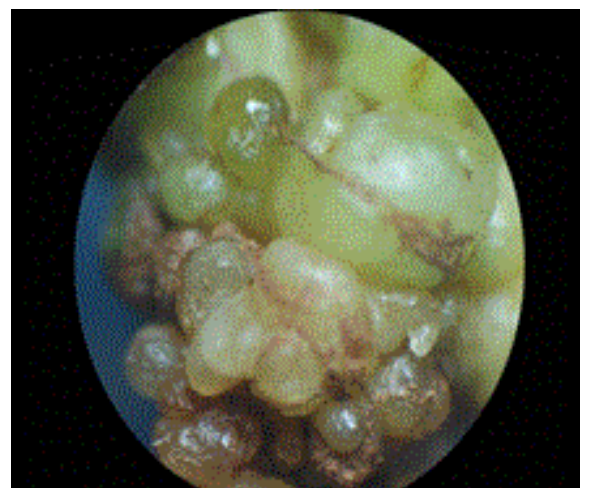

Figure 1e: Microscopic view embryoids.

\begin{tabular}{|c|c|c|c|c|c|c|c|}
\hline \multicolumn{2}{|c|}{ Growth regulator $(\mathrm{mg} / \mathrm{l})$} & \multirow{2}{*}{$\begin{array}{l}\text { Callus } \\
\text { (\%) }\end{array}$} & \multirow[t]{2}{*}{ frequency } & \multirow{2}{*}{$\begin{array}{l}\begin{array}{l}\text { nature of } \\
\text { callusing }\end{array} \\
++\end{array}$} & \multirow{2}{*}{$\begin{array}{l}\text { Callus nature } \\
\text { Crystal white }\end{array}$} & \multirow{2}{*}{$\begin{array}{l}\text { Embryos treatment with BAP } \\
+ \text { IAA+NAA (mg/l) (subculture) }\end{array}$} & \multirow{2}{*}{$\begin{array}{l}\begin{array}{l}\text { No. of shoot sprouting } \\
(\%)\end{array} \\
2.40 \pm 0.13\end{array}$} \\
\hline 2.4-D & 0.5 & & & & & & \\
\hline
\end{tabular}

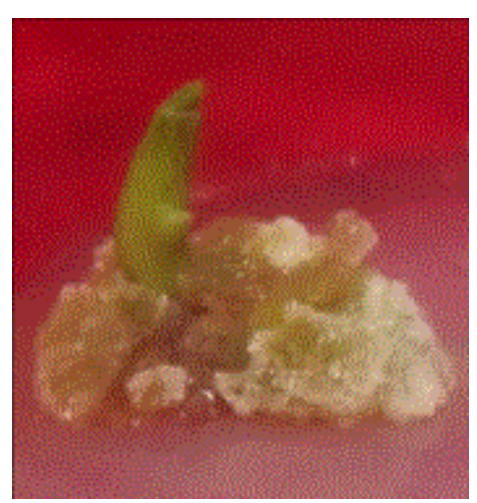

Figure 1f: Callus to shoot induction.

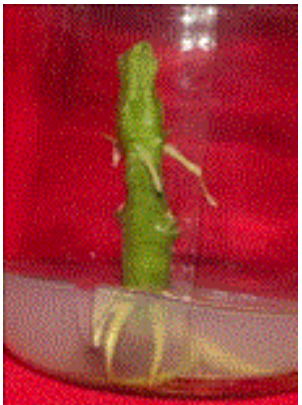

Figure 1g: Rooting of regenerated shoots containing $0.1 \mathrm{mg} / \mathrm{l} \mathrm{NAA}$.

At the concentration of $0.2 \mathrm{mg} / \mathrm{l}$ IAA induced high rooting with 76 per cent, mean root length with $3.92 \pm 0.28 \mathrm{~cm}$, followed by IAA 0.3 $\mathrm{mg} / \mathrm{l}$ induced frequency of rooting 75 per cent, mean root length of $3.08 \pm 0.18 \mathrm{~cm}$ (Table 3 ). Conversely lower concentration of IBA results in formation of roots and higher concentration inhibited the rooting.

\section{Acclimatization}

Development of roots per shoot varied with different treatments. Optimum rooting and growth of shoots were observed on half strength MS medium (Table 4) (Figures $1 \mathrm{~g}$ and $1 \mathrm{~h}$ ). Well-developed root and shoot plantlets were washed with sterile distilled water to remove residual media and transferred to pots containing cocopeat, Cocopeat+ sand and Cocopeat+soil (Figure 1i). After 20 to 25 days plants grown on established well cocopeat when compare with other mixtures. Fully grown plantlets shifted to natural forest soil in green house under controlled conditions (Figure $1 \mathrm{j}$ ). The plantlets resumed good growth after 4 weeks of transplantation. A total of 84 per cent plants survived were shifted to greenhouse condition for hardening. After 25 days, these plants were planted under the canopy of associated Canthium purviflorum plants. 
Citation: Ramachandra Naik M, Rajappa Joga J, Nagaraja N, Nagashree B, Shankramma N, et al. (2017) Micropropagation of Caralluma adscendens var. fimbriata-An Indigenous Medicinal Plant of India. Nat Prod Chem Res 5: 278. doi:10.4172/2329-6836.1000278

Page 6 of 8

\begin{tabular}{|c|c|c|c|c|c|}
\hline & 1.0 & ++ & Greenish white & $1.0+0.2+0.1$ & $2.87 \pm 0.21$ \\
\hline & 1.5 & +++ & Greenish white & $1.5+0.2+0.1$ & $2.67 \pm 0.14$ \\
\hline & 2.0 & +++ & White & $2.0+0.2+0.1$ & $\mathrm{CP}$ \\
\hline \multirow[t]{4}{*}{ NAA } & 0.5 & + & White & $1.0+0.2+0.3$ & $\mathrm{CP}$ \\
\hline & 1.0 & + & Crystal white & $1.5+0.2+0.3$ & $\mathrm{CP}$ \\
\hline & 1.5 & ++ & Crystal white & $2.0+0.2+0.3$ & $\mathrm{CP}$ \\
\hline & 2.0 & ++ & Cream white & $2.5+0.2+0.3$ & $\mathrm{CP}$ \\
\hline \multicolumn{3}{|c|}{ F value } & & & 2.12 \\
\hline
\end{tabular}

Table 3: Effect of different combination of 2.4-D, BAP, NAA, and IAA on callus induction of mature thin explant of $C$. adscendens var. fimbriate.

\begin{tabular}{|c|c|c|c|c|c|c|}
\hline NAA & IAA & IBA & $\begin{array}{l}\% \text { of root } / \text { shoot } \\
\text { response }\end{array}$ & $\begin{array}{l}\text { Mean number of roots } \\
\text { per shoot } \pm \text { SE }\end{array}$ & $\begin{array}{l}\text { Mean length of roots }(\mathrm{cm}) \pm \\
\text { SE }\end{array}$ & Degree Callusing (CP) \\
\hline 0.05 & & & & $3.10 \pm 0.22$ & $4.19 \pm 0.19$ & \\
\hline 0.1 & & & & $5.40 \pm 0.27$ & $5.78 \pm 0.19$ & \\
\hline 0.2 & & & & $3.82 \pm 0.14$ & $4.25 \pm 0.22$ & \\
\hline 0.4 & & & & $2.85 \pm 0.26$ & $3.04 \pm 0.21$ & ++ \\
\hline \multirow[t]{11}{*}{0.6} & & & $\mathrm{CP}$ & & & +++ \\
\hline & 0.2 & & & $3.70 \pm 0.21$ & $3.92 \pm 0.28$ & \\
\hline & 0.3 & & & $3.70 \pm 0.21$ & $3.08 \pm 0.18$ & \\
\hline & 0.4 & & & $2.85 \pm 0.19$ & $2.59 \pm 0.19$ & \\
\hline & 0.5 & & & $2.25 \pm 0.14$ & $1.70 \pm 0.20$ & + \\
\hline & 1.0 & & $\mathrm{CP}$ & & & +++ \\
\hline & & 0.2 & 66.6 & $3.05 \pm 0.24$ & $2.81 \pm 0.17$ & \\
\hline & & 0.4 & 56.6 & $2.30 \pm 0.15$ & $2.10 \pm 0.18$ & \\
\hline & & 0.6 & 43.3 & $2.25 \pm 0.14$ & $1.30 \pm 0.11$ & + \\
\hline & & 0.8 & $\mathrm{CP}$ & & & ++ \\
\hline & & 1.0 & Nill & & & +++ \\
\hline \multicolumn{4}{|c|}{$F$ value } & 19.2 & 40.1 & \\
\hline
\end{tabular}

Table 4: Rooting response of in vitro regenerated shoots of $C$. adscendens var. fimbriata in half strength MS media containing NAA, IAA and IBA in various concentrations with $1 \%$ sucrose after one month of culture. 
Citation: Ramachandra Naik M, Rajappa Joga J, Nagaraja N, Nagashree B, Shankramma N, et al. (2017) Micropropagation of Caralluma adscendens var. fimbriata-An Indigenous Medicinal Plant of India. Nat Prod Chem Res 5: 278. doi:10.4172/2329-6836.1000278

Page 7 of 8

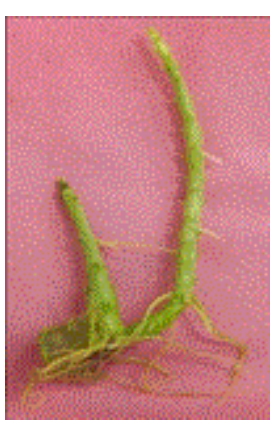

Figure 1h: Rootlet plant.

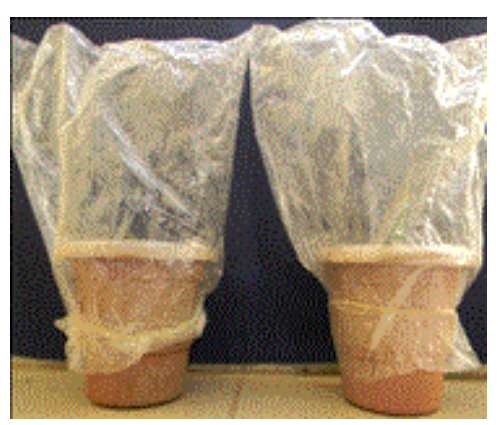

Figure 1i: Polythin covered pots.

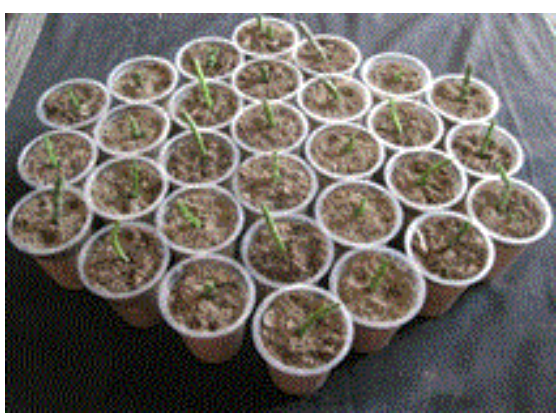

Figure 1j: Plants growing in forest soil under polyhouse.

\section{Acknowledgement}

The authors would like to thanks to University grant commission, New Delhi for to Rajiv Gandhi fellowship to Ramachandra Naik for financial support to conduct this research.

\section{References}

1. Jagtap A, Singh NP (1999) Fascicles of flora of India Botanical survey of India, Kalkata. Fascicle 24: 201-202.

2. Kumari GR, Rao GVS (1976) A new species of Caralluma Asclepiadaceae from India. J Bom Natu His Soc 73: 194-196.

3. Gilbert MG (1990) A review of Caralluma $\mathrm{RBr}$ and its segregates. Bradleya 8: 1-32.
4. Meve U, Heneidak S (2005) A morphological, karyological \& chemical study of the Apteranthes, Caralluma europaea complex. Biol J Linnean Soc 419-432.

5. Ugraiah AV, Raja S, Reddy PVK, Rajasekhar K, Rani SS, et al. (2011) In vitro shoot multiplication \& conservation of Caralluma bhupenderiana Sarkaria-an endangered medicinal plant from South India. Afric J Biotech 10: 9328-9336.

6. Lawrence RM, Choudary S (2004) Caralluma fimbriata in the treatment of obesity; 12th Annu W Congr on Antiaging Medicine, Las Vegas, NV.

7. Rathore MS, Singh B, Kataria V, Shekhawat NS (2009) Micropropagation of Medicinal Plants of Indian Desert and Aravallies. Plant Tissue Culture \& Molecular Markers: Their Role in Improving Crop Productivity. IK International, India, pp: 281-289.

8. Hirschmann SG, Jordan M, Gerth A, Wilken D, Hormazabal E, et al. (2004) Secondary Metabolite Content in Fabiana Imbricate plants \& in vitro cultures. Z Naturforsch 59: 48-54.

9. Mukunga NP, Jager AK, Van Staoen J (2003) Micropropagation of Thapsia gargania-a medicinal plant. Plant Cell Rep 21: 967-973.

10. Aruna V, Kiranmai C, Karuppusamy S, Pullaiah T (2009) Micropropagation of three varieties of Caralluma adscendens via Nodal Explants. J Plant Biochem Biotech 18: 121-123.

11. Sreelatha RV, Pullaiah T (2010) Induction of Somatic Embryogenesis and Plant Regenaration from Internodal Explants of Caralluma stalagmifera. Botany Res Intern 3: 17-20.

12. Kaur G, Rathore TS, Rao SR, Shekhawat NS (1992) In vitro mircopropagation of Caralluma edulis, Edgew Benth and Hook, Rare edible plant species of Indian desert. Indian J Plant Gen Res 5: 51-56.

13. Thomas TD, Philip B (2005) Thidiazuron-induced high frequency shoot organogenesis from leaf derived callus of a medicinal climber, Tylophora indica Burn Merrill. In-vitro Cell Dev Biol Plant 41: 124-128.

14. Rehman R, Fayyaz Chaudhary M, Fatima Rizvi Z, Ul Haq I, Zia M (2014) In vitro propagation of chungah (Caralluma tuberculata NE Brown). Pak J Bot 46: 2189-2194.

15. Komalavalli N, Rao MV (2000) In vitro micropropagation of Gymnema sylvestre-A multipurpose medicinal plant. Plant Cell Tissue Organ Cult 61: 97-105.

16. Sreekumar S, Seeni S, Pushpangadan P (2000) Micropropagation of Hemidesmus indicus for cultivation \& production of 2-hydroxy 4methoxy benzaldehyde. Plant Cell Tissue Organ Cult 62: 211-218.

17. Sokal RR, Rohlf FJ (1987) Introduction to biostatistics. WH Freeman, New York.

18. Reddy PS, Gopal GR, Sita GL (1998) In vitro multiplication of Gymnema sylvestre RBr-An important medicinal palnt. Curr Sci 75: 843-845.

19. Beena MR, Martin KP, Kirti PB, Molly H (2003) Rapid in vitro propagation of medicinally important Ceropegia $c$ and elabrum. Plant Cell Tissue Organ Cult 72: 285-289.

20. Martin KP (2002) Rapid propagation of Holostemma ada-kodien Schult, a rare medicinal plant, through axillary bud multiplication \& indirect organogenesis. Plant Cell Rep 21: 112-117.

21. Koroch AR, Juliani HR, Trippi VS (1997) Micropropagation and acclimatization of Hedeoma multiflorum. Plant Cell Tissue Organ Cult 48: 213-216.

22. Tavares AC, Pimenta MC, Gonsalves MT (1996) Micropropagation of Melissa officinalis L through proliferation of axillary shoots. Plant Cell Rep 15: 441-444.

23. Faisal M, Anis M (2002) Rapid in vitro propagation of Rauvolfia tetraphylla L-An endangered medicinal plant. Physiol Mol Biol Plants 8: 295-299.

24. Fraternale D, Giamperi L, Ricci D, Rochhi MBI (2002) Micropropagation of Bupleurum fruticosum: the effect of triacontanol. Plant Cell Tissue Organ Cult 69: 135-140.

25. Vyapari S, Khatamian H, Albrecht ML (1993) In vitro regeneration in Asclepias tuberose. Hort Sci 28: 508. 
Citation: Ramachandra Naik M, Rajappa Joga J, Nagaraja N, Nagashree B, Shankramma N, et al. (2017) Micropropagation of Caralluma adscendens var. fimbriata-An Indigenous Medicinal Plant of India. Nat Prod Chem Res 5: 278. doi:10.4172/2329-6836.1000278

Page 8 of 8

26. Sarasan V, Sonia EV, Nair GM (1994) Regeneration of Indian sarsaparilla, Hemidesmus indicus $\mathrm{RBr}$ through organogenesis and somatic embryogenesis. Ind J Exp Bio 32: 284-287. 